\title{
ブラシノステロイド情報层達タソパク質BSS1の「集合と拡散」による植物草丈制御㙨構 植物ヶミカルバイオロジーが明らかにした新たなタンパク質のダイナミクス
}

ステロイドホルモンは動物から昆虫，植物にわたって 広く保存される生理活性化合物である。植物におけるス テロイドホルモンは，ブラシノステロイドと総称され， 植物の生長を総じて促進的に制御する生理機能が明らか にされている．発見当初は，その活性に基づき，ブラシ ノステロイドの農業利用が検討されたが，高額な全合成 費用などが障壁となって，実用化には至っていない。

植物ブラシノステロイドの生合成機構は, 実験植物ア ラビドプシスがブラシノステロイド久損によって矮性形 質を示す現象に着目した分子遺伝学研究によって, 現在 では主要な部分が明らかにされている。このような天然 化合物の生理活性発現機構研究において, 生合成経路研 究と並んで重要であるのは，情報伝達経路の研究である と考えられる。ブラシノステロイドにおいては，矮性形 質がブラシノステロイド添加によって回復しない, ブラ シノステロイド不感受性突然変異体の探索によって，細 胞外にLRRドメインをもつ一回膜貫通型キナーゼであ る受容体 $\mathrm{BRI} 1^{(1)}$ とその近傍の遺伝子 2 種が単離された. しかし，その後，機能欠損型の突然変異体の解析のみで は，情報伝達因子の探索研究が停滞する時期が続いた.

この状況下において, 筆者らの共同研究チームは, ブ ラシノステロイド生合成阻害剂 $\mathrm{Brz}^{(2)}$ を用いて，機能獲 得型突然変異体を対象としたスクリーニングを行うケミ カルバイオロジー研究を開始し，その打開を試みた。第 一に得られた突然変異体bil1（Brz-insensitive-long hypocotyl1）/bzr1（Bzr-resistant1）はbHLH型転写因子の 高蓄積化が変異原因であり ${ }^{(3)}$, その後の研究によって, アラビドプシスの全ゲノム遺伝子約 30,000 種のうち，約 3,000 遺伝子の発現を制御するマスター転写因子である ことなどが明らかとなってきた ${ }^{(4,5)}$.この BIL1/BZR1 夕 ンパク質は，細胞質に存在し，ブラシノステロイド刺激 によって核内に移行するという興味深い性質をもつ転写 因子でもある (3). しかし，この核移行の制御機構は未解 明のままで残されていた。本稿では，このBIL1/BZR1 核移行制御機構の一端を解明した成果について紹介したい.

暗所発芽した植物は徒長した黄化胚軸形態を示すが, ブラシノステロイド生合成阻害剂 Brz 存在下で暗所発芽 した植物は，胚軸が太く短くなり，子葉が開化した暗所
光形態形成を示す，bill変異体は，Brzに耐性を示し胚 軸が徒長する変異体として単離したが，逆に，このBrz によって，野生型に比べて，より肧軸が短化する機能獲 得型の突然変異体bss1（Brz-sensitive-short1）を単離し た ${ }^{(6)} . b s s 1$ 変異体は，その変異体においてブラシノステ ロイド応答性遺伝子マーカーの発現が抑制されており, 逆に原因遺伝子の破壊型変異体では，マーカー遺伝子の 発現は促進されていた。 また，bss1変異体は，成熟時に は花茎がほとんど認められない極端な矮性形態を示し， その形態は既知のブラシノステロイド生合成・情報伝達 欠損型変異体や Brz 処理植物体と類似する形態と考えら れた。これらのことから，変異原因遺伝子BSSIは，ブ ラシノステロイド情報伝達の抑制因子であり，その高発 現によってブラシノステロイド抑制型の形質が変異体に おいて現れていると考察された.

BSS1タンパク質は, タンパク質-タンパク質間の相互 作用にかかわる Ankyrinリピートドメインをもってい た，その細胞内における機能を解明するため, BSS1GFP形質転換体を作成したところ，細胞質において， タンパク質複合体に由来するドット状の蛍光シグナルと して観察された。さらに非常に興味深いことに，この ドット状蛍光シグナルは, Brz处理によって, ドット数 が増加し，逆に，ブラシノステロイド処理によって， ドットが消失して細胞質全体に薄く広がった蛍光シグナ ルが観察された．これらの反応は，根と胚軸の双方で認 められ，最短15分の处理によっても観察された。すな わち，BSS1タンパク質は，Brz処理によって「集合」 してタンパク質複合体を形成し，その複合体はブラシノ ステロイド処理によって「拡散」することが明らかと なった。

つづいて，BSS1タンパク質の細胞内局在性に基づき， 先に得られていたブラシノステロイドのマスター転写因 子 BIL1 との関係性を $\mathrm{Y} 2 \mathrm{H}$ 法, BiFC法, 免疫沈降法に よって解析した結果，BSS1 とBIL1は，細胞質において 直接的に相互作用することが明らかとなった。そこで, BIL1-GFP形質転換体とBSS1 高発現形質転換体打よび $B S S 1$ 欠損変異体との二重変異体を作出したところ, BSS1 高発現状況においてBIL1-GFPの細胞核内におけ 


\section{ブラシノステロイド含量}

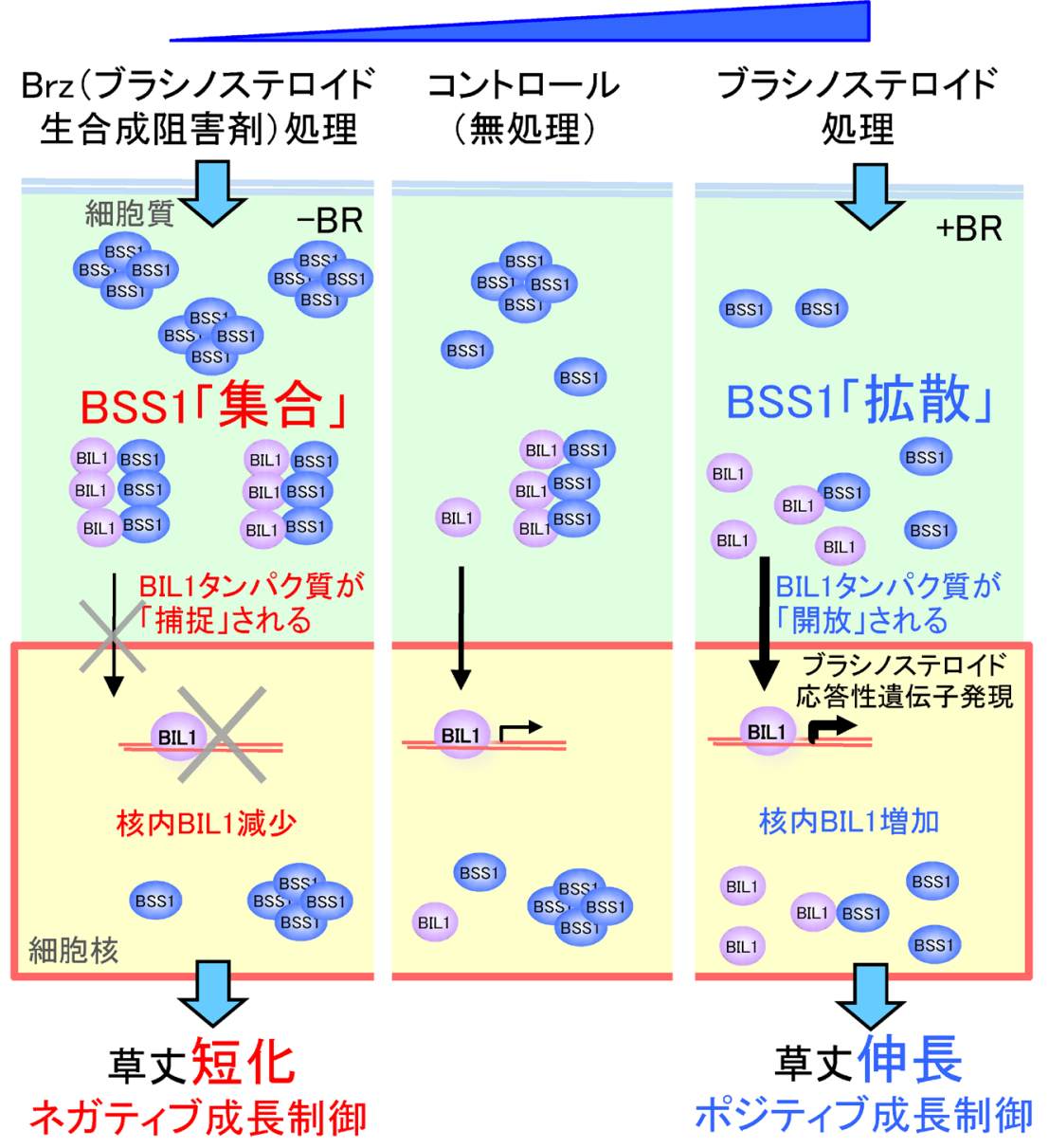

る蛍光シグナルが低下すること，BSS1 低発現状況にお おいて非常に重要である.さらに近年は植物バイオマス いてはBIL1-GFP核内シグナルが増加することが，明ら かになった。これらの結果より, BSS1がBIL1の細胞質 から核への移行をネガティブに制御していることを示す と考えられた。

以上の結果より，BSS1の機能についての作業仮説を 考察した（図1).ブラシノステロイド低下状況（図中 左側）では, BSS1は「集合」してタンパク質複合体を 形成し，そのBSS1複合体にBIL1タンパク質が捕捉さ れ，細胞質から核へのBIL1の移行が抑制されて，草丈 は短くなる．ブラシノステロイド添加状況では, BSS1 の複合体は「拡散」し，モノマーとなったBSS1から BIL1は解放されて, 細胞質から核内へBIL1は移行し, 草丈は伸長する。このようなBSS1タンパク質複合体の 集合と拡散が, BIL1の核移行の制御を通じて, 草丈の 制御を行っている，と考察された。

植物草丈の制御技術は, 農業上の作物・穀物の育種に であると考えられている，今後さらに詳細なブラシノス テロイド情報伝達機構の解明によって, 植物草丈制御技 術の応用展開が進むものと期待される.

1) J. Li \& J. Chory: Cell, 90, 929 (1997).

2) T. Asami \& S. Yoshida: Trends Plant Sci., 9, 348 (1999).

3) Z. Wang, T. Nakano, J. Gendron, J. He, M. Chen, D. Vafeados, Y. Yang, S. Fujioka, S. Yoshida, T. Asami et al.: Dev. Cell, 2, 505 (2002).

4) J. X. He, J. M. Gendron, Y. Sun, S. S. Gampala, N. Gendron, C. Q. Sun \& Z. Y. Wang: Science, 307, 1634 (2005).

5) Y. Sun, X. Y. Fan, D. M. Cao, W. Tang, K. He, J. Y. Zhu, J. X. He, M. Y. Bai, S. Zhu, E. Oh et al:: Dev. Cell, 19, 765 (2010).

6) S. Shimada, T. Komatsu, A. Yamagami, M. Nakazawa, M. Matsui, H. Kawaide, M. Natsume, H. Osada, T. Asami \& T. Nakano: Plant Cell, 27, 375 (2015).

(中野雄司 $* 1,3$, 浅見忠男 $* 2,3,{ }^{* 1}$ 理化学研究所環境資源 科学研究センター, *2 東京大学大学院農学生命科学研 究科, ${ }^{* 3}$ JST-CREST) 


\section{今日の話題}

プロフィル

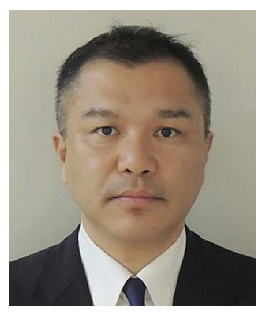

中野 雄司 (Takeshi NAKANO)

<略歴>1994年京都大学大学院農学研究

科農芸化学専攻博士課程修了／同年日本学

術振興会特別研究員 (PD) / 1995年理化学

研究所基礎科学特別研究員 $/ 1996$ 年同研

究員 $/ 2000 \sim 2002$ 年米国ソーク研究所博

士研究員 $/ 2007$ 2011年JST-さきがけ,

さきがけ研究者 $/ 2005$ 年理化学研究所専

任研究員, 現在に至るく研究テーマと抱

負>ケミカルバイオロジーの力を借りて,

植物の生長・生命力・進化の原理を探り,

社会に活かす＜趣味 > 登山, ダイビング,

自転車

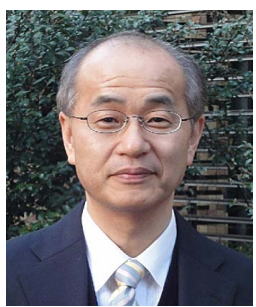

浅見 忠男（Tadao ASAMI）

<略歴>1982年東京大学農学部農芸化学 科卒業 / 1987 年同大学大学院農学系研究 科農芸化学専攻博士課程修了/同年日本特 殊農薬製造 (株) 入社 $/ 1991$ 年理化学研究 所入所 $/ 2006$ 年東京大学大学院農学生命 科学研究科教授, 現在に至る<研究テーマ と抱負 >活性化合物の創製とその作用機構 の解明を通して生物活性物質で世界に幸福 をもたらしたいく趣味>球技（卓球，バド ミントン, テニス, ソフトボールなどボー ルが小さい方), 音楽と運動の調和 $<$ 所属 研究室ホームページ>http://pgr.ch.a. u-tokyo.ac.jp/

Copyright (C) 2015 公益社団法人日本農芸化学会 DOI: 10.1271/kagakutoseibutsu.53.734 